[Agr. Biol. Chem., Vol. 25, No. 5, p. 389 393, 1961]

\title{
Studies on Pectolytic Enzymes of Molds
}

\section{Part II. On the Pectolytic Activities of Several Molds}

\author{
By Akira ENDo \\ Takamine Laboratory, Sankyo Co., Ltd., Tokyo
}

Received December 8, 1960

\begin{abstract}
According to the results of experiments on pectolytic enzymes produced by several sorts of molds, no parallel relationship could be observed between such activities on pectic substances as formation of reducing radicals, reduction of viscosity or pectin esterase and the fruit juice clarifying activity. A parallel relationship holds true between the reduction of viscosity of fruit juice and the fruit juice clarifying activity. Pectin esterase intensified the activity of some molds to hydrolyze pectic substances, but did not at all influence the same activity of others. Although pectin esterase displayed an action to intensify fruit juice clarification, it deteriorated clarity when excessive.
\end{abstract}

Very few experiments have hitherto been carried out in regard to the pectolytic enzymes of molds in connection with the fruit juice clarifying phenomenon. Seegmiller and Jansen ${ }^{1)}$ reported that polymethylgalacturonase (PMG) was present in "Hydralase" which was a commercially available pectolytic enzyme preparation. Satomura ${ }^{2)}$ discovered that Sclerotinia libertiana in solid culture had a strong fruit juice clarifying activity, and Takehana and Ogura ${ }^{3}$ examined the various decomposing activities of the said microorganism on pectic substances. Schubert ${ }^{4)}$ considered that the factor to decompose native pectin present in fruit juice is different from other polygalacturonases (PG). Joslyn, Mirst and Lambert ${ }^{5}$ ) measured the PG and pectin esterase (PE) of commercially available enzyme preparations. Recently Neu-

\footnotetext{
1) C.G. Seegmiller and E.F. Jansen, J. Biol. Chem., 195, 327 (1952).

2) Y. Satomura, J. Agr. Chem. Soc. Japan, 26, 486 (1952)

3) H. Takehana and N. Ogura, ibid. 28, 881 (1954).

4) E. Schubert, Nature, 169, 931 (1952).

5) M.A. Joslyn, S. Mist and E. Lambert, Food Technol., 6, 133 (1952).
}

beck $^{6}$ ) reported, in regard to several sorts of enzyme preparations, on the relations between their various activities on pectic substances and their apple juice clarifying activity.

In the present report will be described the results of a few experiments, in regard to the microorganisms discussed in the previous report 7 ), on their various activities on pectic substances and their fruit juice clarifying activity, and on the effect of addition of PE on the enzymes of these microorganisms.

\section{MATERIALS AND METHODS}

\section{(I) Materials.}

(1) Enzyme preparations: Refined defatted rice bran was used as a culture medium for various microorganisms, and cultivation was continued for 3 to 5 days at a temperature of $26^{\circ} \mathrm{C}$. After completion of cultivation, acetone was added under refrigeration to the water extract of the rice bran, and then-formed precipitate was separated centrifugally, dried and was used as enzyme sample. In experimentation, such an enzyme sample was dissolved in a certain quantity of water, deprived of impurities by filtration, and was

6) E. Neubeck, J. Assoc. Offic. Agr. Chemists, 42, 374 (1959).

7) A. Endo, and Y. Miura, This Journal, 25, 383 (1961). 
used as enzyme solution.

(2) Pectin and pectic acid: Pectin used was, as in the previous report, citrus pectin (Manufactured by Biddle-Sawyer Corp.). Pectic acid was prepared from the above-mentioned pectin sample by Jansen and MacDonnell's method ${ }^{8)}$.

(3) Pectin esterase (PE): The product of Nutritional Biochemicals Corporation was used.

(4) Fruit juice: Fruit juice used was 1/10-diluted fluid of "Orange Conc." which was a concentrated orange juice product manufactured by Nankai Kako K.K.. The precipitate formed by dilution was removed by centrifugal process at 3,500 r.p.m. for 5 minutes.

\section{(II) Methods.}

(1) Polygalacturonase assay: By a variation of the Willstätter-Schudell hypoiodite method ${ }^{9)}$, the increase of reducing groups formed by hydrolysis of the glycoside linkages was measured. To $5 \mathrm{ml}$ of $1 \%$ solution of pectin or pectic acid containing $0.2 \mathrm{~m}$ acetate buffer ( $\mathrm{pH} 4.0$ ) were added $1 \mathrm{ml}$ of the enzyme solution and water to make the total quantity $10 \mathrm{ml}$, and the reaction mixture was kept at $30^{\circ} \mathrm{C}$.

Aliquots of $5 \mathrm{ml}$ were removed at definite time intervals and added to $1 \mathrm{ml}$ of $1 \mathrm{M} \mathrm{Na}_{2} \mathrm{CO}_{3}$ in a glassstoppered Erlenmyer flask, followed by $5 \mathrm{ml}$ of standard $0.1 \mathrm{~N}$ iodine. After standing for exactly $20 \mathrm{~min}$ utes, the reaction mixture was acidified with $2 \mathrm{M}_{2} \mathrm{HO}_{4}$ and the residual iodine was titrated with standard $0.05 \mathrm{~N}$ thiosulfate solution. The microequivalents of reducing groups liberated were determined against a

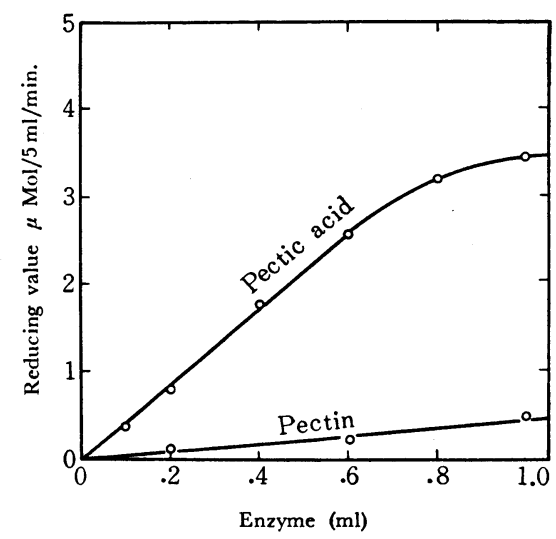

FIG. 1. Relation between Initial Rate of Hydrolysis and Enzyme Concentration ( $C$. diplodiella).

8) E.F. Jansen and L.R. MacDonnell, Arch. Biochem., 8, 97 (1945).

9) R. Willstätter and G. Schudell, Ber., 51, 780 (1918). standard curve prepared from data obtained with galacturonic acid monohydrate. The conditions of the assay permitted use of the linear portion of the standard curve (Fig. 1). In this range 1 microequivalent of $I_{2}$ reduced corresponded to the liberation of 0.513 microequivalent of galacturonic acid monohydrate. The activities are reported in microequivalents of reducing groups liberated from pectin or pectic acid per minute per unit of enzyme, i.e., (PG.u $)_{\mathrm{ml}}$, (PMG.u $)_{\mathrm{ml}}$, (PG.u $)_{\mathrm{mg}}$, and (PMG.u) mg $_{\text {, PG.u }}$ and PMG.u stand for the activities when pectic acid and pectin are used respectively as substrates.

(2) Pectin esterase (PE) assay: Jansen and MacDonnell' ${ }^{8)}$ method was adopted. The composition of the reaction mixture was the same as that of PG assay, and the reaction mixture was kept at a temperature of $30^{\circ} \mathrm{C}$ for a definite length of time. Ten $\mathrm{ml}$ each of the mixture were taken at certain intervals, and were titrated with $0.02 \mathrm{~N} \mathrm{NaOH}$ using a glass electrode. The results are expressed in terms of specific activities, i.e., microequivalents of carboxyl groups liberated per minute per aliquot of enzyme, designated by symbols (PE.u)ml. or (PE.u) mg.

(3) Pectin viscosity: The viscosity was measured by Roboz, Barratt and Tatum's method ${ }^{10)}$ with the Ostwald viscosimeter. The enzymatic activity was expressed in terms per cent viscosity change. The composition of the reaction mixture and reacting conditions were exactly the same as those of PG assay. The reducing rate of viscosity was calculated from the following equation.

$$
A=\frac{V o-V t}{V o-V s} \times 100
$$

$V o=$ flow time in seconds of pectin + inactivated enzyme; $V t=$ flow time in seconds at reaction time of pectin + active enzyme; $V s=$ flow time is seconds of the solvent (water) + inactivated enzyme.

One unit of viscosity reducing activity is defined as quantity of enzyme necessary for $50 \%$ viscosity change of $10 \mathrm{ml}$ of the reaction mixture per minute at $30^{\circ} \mathrm{C}$, and designated by symbol (VR.u) .

\section{RESULTS AND DISCUSSION}

\section{(I) Relations between the Pectolytic Activities and the Fruit Juice Clarifying Activity of the Enzymes of Each Microorganism.}

As criteria for measuring enzymatic activi-

10) E. Roboz, R.W. Barratt and E.L. Tatum, J. Biol. Chem., 195, 459 (1952). 
ties to decompose pectic substances, the formation of reducing radicals, viscosity reducing activity and PE activity are usually taken into consideration when pectin is adopted as substrate. In considering decomposition of pectic acid, the viscosity reducing activity and formation of reducing radicals are commonly measured.

The relations between the various activities mentioned above and the fruit juice clarifying activity were examined by comparing different samples of $C$. diplodiella as well as those of different microorganisms, and the results are given in Tables I and II. In case of samples

Table I. Pectolytic Activities of Some Preparations From $C$. diplodiella

$\begin{array}{cccccc}\begin{array}{c}\text { Sample } \\ \text { No. }\end{array} & \begin{array}{c}\text { (PMG.u) } \\ \text { ml }\end{array} & \begin{array}{c}\text { (PG.u) } \\ \text { ml }\end{array} & \begin{array}{c}\text { (PE.u) } \\ \text { ml }\end{array} & \begin{array}{c}\text { (VR.u) } \\ \text { ml }\end{array} & \begin{array}{c}\text { Juice- } \\ \text { clarifying } \\ \text { Activities }\end{array} \\ 1 & 0.288 & 2.05 & 0.034 & 32.0 & 2400 \\ 2 & 0.305 & 2.10 & 0.034 & 35.1 & 2600 \\ 3 & 0.249 & 1.95 & 0.031 & 30.0 & 2100 \\ 4 & 0.326 & 2.32 & 0.036 & 36.6 & 2800 \\ 5 & 0.410 & 2.80 & 0.045 & 40.2 & 3100\end{array}$

of $C$. diplodiella cultured under the approximately same conditions, the fruit juice clarifying activity slightly varied with samples, and the activities to decompose pectin or pectic acid varied proportionally. On the other hand, in comparing the various activities with the fruit juice clarifying activity of different microorganisms, as indicated by Table II, in no case was observed a parallel relationship between the fruit juice clarifying activity and any other activity.

A parallel relationship was observed between the reduction of the viscosity of fruit juice in the course of clarification and the clarifying activity, in other words the flocculating activity. The relative ratios of the various activities of these microorganisms widely very with the strains (Table III). It is presumed that the types and quantities of pectolytic enzymes considerably vary with types of microorganisms, and that a joint action of such enzymes reduces the viscosity of fruit juice and clarifies it.

Table II. Pectolytic Activities of Some fungal Enzyme Preparations

$\begin{array}{lcccccc}\text { Microorganisms } & \text { (PMG.u) } \mathrm{ml} & \text { (PG.u) } \mathrm{ml} & \text { (PE.u) } \mathrm{ml} & \text { (VR.u) } \mathrm{ml}^{1)} & \text { (VR.u) } \mathrm{ml}^{2)} \begin{array}{c}\text { Juice-clarifying } \\ \text { activities }^{(\mathrm{V}}\end{array} \\ \text { C. diplodiella } & 0.288 & 2.05 & 0.034 & 32.0 & 20 & 2400 \\ \text { B. cinerea } & 0.275 & 0.84 & 0.039 & 4.4 & 6.1 & 760 \\ \text { Ag. capentris } & 0.042 & 0.44 & 0 & 10.0 & 6.5 & 640 \\ \text { P. citrinum } & 0.009 & 0.04 & 0 & 0.32 & 5.4 & 420 \\ \text { S. libertiana } & 0.234 & 0.99 & 0.089 & 6.8 & 6.1 & 620 \\ \text { Car. javanicus } & 0.047 & 0.06 & 0 & 0.1> & 1.8 & 120 \\ \text { A. niger } & 0.189 & 0.72 & 0.013 & 5.6 & 0.9 & 100\end{array}$

$\begin{array}{ll}\text { 1) pectin solution } & \text { 2) orange juice }\end{array}$

Table III. Ratio of Each Pectolytic ACtivity

Microorganisms $\frac{\text { (PG.u) }}{\text { (PMG.u) }} \frac{\text { (PMG.u) }}{\text { (PE.u) }} \frac{\text { (PG.u) }}{\text { (PE.u) }} \frac{\text { (VR.u) }}{\text { (PMG.u) }}$

(II) Effect of Addition of PE on Pectolysis by Enzymes of Each Microorgamanisms.

Jansen and MacDonnell11), using a com$\begin{array}{lllll}\text { C. diplodiella } & 7.1 & 9.00 & 64.0 & 110\end{array}$

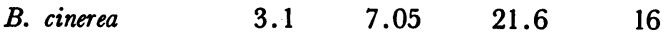

Ag. capentris $\quad 10.3 \quad-\quad \quad-\quad 240$

$\begin{array}{lllll}P . & \text { citrinum } & 4.4 & - & -\end{array}$

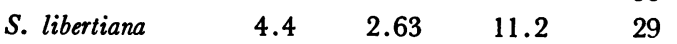

$\begin{array}{lllll}\text { Car. javanicus } & 1.3 & - & - & 2>\end{array}$

$\begin{array}{lllll}\text { A. } \text { niger } & 3.8 & 10.45 & 55.3 & 30\end{array}$

mercially available pectolytic enzyme product, observed that addition of PE significantly accelerated pectolysis, and Luh and Phaff ${ }^{12)}$, using PG of yeast, observed a similar effect.

11) E.F. Jansen, L.R. MacDonnell and R. Jang, Arch. Biochem., 8, 113 (1945).

12) B.S. Luh and H.J. Phaff, Arch. Biochem. Biophys., 48, 23 (1954). 


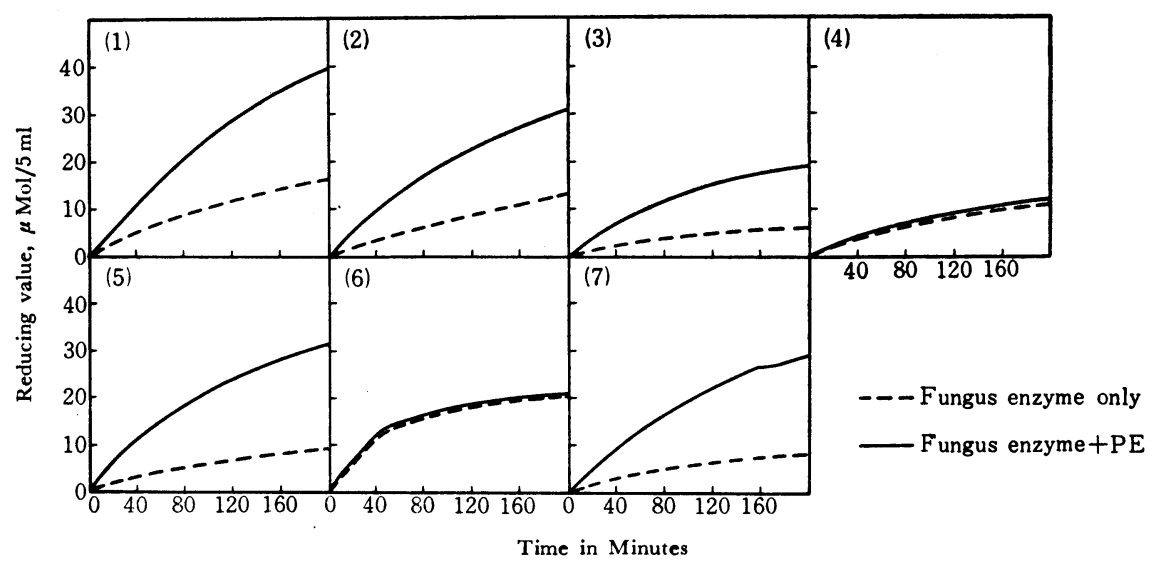

FIG. 2. Effect of Added PE upon Pectin Hydrolysis by Some Molds Enzymes.

Concentration of each enzyme solution is arbitrary.

(1) C. diplodiella (2) B. cinerea (3) Ag. capentris (4)

P. citrinum

(5) S. libertiana

(6) Car. javanicus

(7) A. niger.

It is presumable that pectolytic activity is accelerated by the addition of PE when enzymes belonging to PG are involved. Fig. 2 shows the results of a test in which the effect of addition of PE to pectolysis was observed in regard to each microorganism. The pectolytic activities of five microorganisms, C. diplodiella, B. cinerea, Ag. capentris, S. libertiana and $A$. niger, were obviously intensified by addition of PE. The two other microorganisms, however, were scarcely affected. Thus the present experiment has disclosed that some of the microorganisms which have an activity to clarify fruit juice are hardly affected of their pectolytic activities by addition of PE. In no case was observed inhibition of pectolysis by the presence of $\mathrm{PE}$.

(III) Effect of Addition of PE on Clarification of Fruit Juice.

As already stated, PE sometimes accelerates hydrolysis of pectin. Clarification of orange juice is also favorably affected by $\mathrm{PE}$ in many cases (Table IV). When fruit juice is clarified, flocculation at first occurs to form flocks, which gradually grow in size and start precipitating. Supernatant fluid is then formed, and thus the clarifying phenomenon is ob-
TABle IV. The EFFect OF ADDED PE ON JUICE-CLARIFYING ACTIVITIES OF SOME MOLDS ENZYMES PREPARATIONS

\begin{tabular}{|c|c|c|c|c|}
\hline \multirow[b]{2}{*}{ Microorganisms } & \multicolumn{2}{|c|}{ Control } & \multicolumn{2}{|c|}{$\mathrm{PE}$ added } \\
\hline & $\begin{array}{l}\text { Time for } \\
\text { clarification } \\
\text { (min) }\end{array}$ & Glarity & $\begin{array}{l}\text { Time for } \\
\text { clarification } \\
\text { (min) }\end{array}$ & Clarity \\
\hline C. diplodiella & 27 & 冊 & 18 & 世 \\
\hline B. cinerea & 36 & W & 25 & H \\
\hline Ag. capentris & 50 & $H$ & 37 & + \\
\hline$P$. citrinum & 55 & $H$ & 50 & H \\
\hline S. libertiana & 50 & 冊 & 37 & $H$ \\
\hline Car. javanicus & 36 & 冊 & 33 & \# \\
\hline A. niger & 35 & 冊 & 25 & 世 \\
\hline Pectin Esterase & 150 & cloud & - & - \\
\hline
\end{tabular}

served. The accelerating effect of PE was hardly seen on two microorganisms, $P$. citrinum and Car. javanicus, as in the case with pectin adopted as substrate. In the case of the five other microorganisms, the time required to start flocculation was shortened, and the precipitation of the flocks formed was also accelerated. Thus the same accelerating effect as in the case of pectolysis was observed. When PE was applied independently, flocculation was incomplete, the amount of precipitate was little, and clarification did not take place. Supernatant portion was 
hardly formed and, if any, was not clear.

In case of the five microorganisms, the juice clarifying activity was accelerated by $\mathrm{PE}$, but clarity deteriorated except in the case of $A$. niger. The deterioration of clarity was aggravated as the quantity of PE was increased. When pectic substance in fruit juice is decomposed, if PE alone acts at first, behavior resembling that of pectic acid is observed, since hydrolysis of glycoside bonds scarcely takes place and free carboxyl radicals are formed. Pectic acid which is sensitive to acid and polyhydric cations and readily forms sediments is easily made to precipitate. When $\mathrm{PE}$ alone is applied, the formation of incomplete precipitates take place presumably by such a route. When hydrolysis of methoxyl bonds is exceedingly rapid as compared with that of glycoside bonds, flocculation and precipitation are accelerated, but clarity gradually deteriorates as in case of application of PE alone. Although the fruit juice clarifying activity of microorganisms which have little $\mathrm{PE}$ is strengthened by addition of PE, excessive addition reduces clarity and unfavorably affects the clarifying effect.

Acknowledgement The author's hearty gratitude to Professors K. Shimura and T. Uemura, Tohoku University, is hereby expressed for their helpful guidance. $\mathrm{He}$ is also gratefully indebted to Mr. Matsui, director of the Research Department, Mr. Nakamura, chief of the Tanashi Plant, Dr. Okazaki and Mr. Miura, heads of the laboratory, for the advices and conveniences they offered to the author. 